JURNAL INKLUSIF : Jurnal Pengkajian Penelitian Ekonomi dan Hukum Islam Vol:4 No:1 Juni 2019 Published by Pascasarjana IAIN Syekh Nurjati Cirebon, Indonesia. p-ISSN: 2303-2669, e-ISSN: 2548-9631

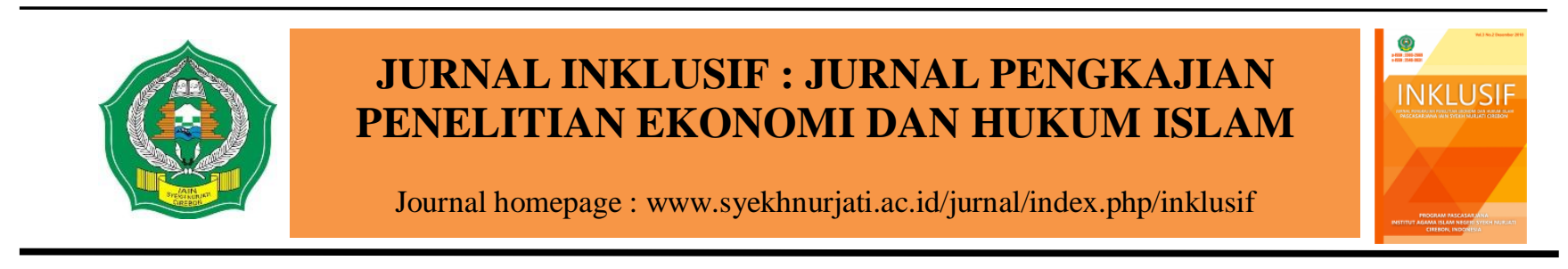

\title{
IMPLEMENTASI EKONOMI SYARIAH PADA PERKEMBANGAN INVESTASI SAHAM SYARIAH DI ERA DISTRUPSI \\ Dini Selasi ${ }^{1}$ \\ Email : diniselasi1980@gmail.com
}

\section{Artikel info:}

Received: 18

Maret 2019

Revised form: 27

April 2019

Accepted: 27 April

2019

Available online:

17 Mei 2019

\section{ABSTRACT}

The implementation of Islamic economics can be done in various aspects of human life, including in trade. This study aims at how the application of Islamic economics in the development of Islamic stock investment then how to become investors and the latest developments in Islamic stock investment - the method used to determine the validity of a study, using various techniques as well. The researcher used the library research method. Library research is a study conducted in the library taking library settings as a place of research with the object of research are library materials, research dealing with various literature following the objectives and problems that will and are being studied. The result of this research is how to become an investor; prepare personal data, register with securities companies, start stock investments. The implementation of Islamic financing in halal stock investment is indicated by the suggestion of the Quranic Letter of Yusuf(46-49), hadith, DSN-MUI fatwa and extraordinary developments in Islamic stock investment.

Keywords: sharia economy, investment, sharia shares

\section{ABSTRAK}

Penerapan ekonomi syariah bisa dilakukan dalam berbagai aspek kehidupan manusia, termasuk dalam perdagangan/muamalah. Penelitian ini bertujuan bagaimana implementasi ekonomi syariah pada perkembangan investasi saham syariah kemudian cara menjadi investor dan perkembangan terkini tentang investasi saham syariah. metode yang digunakan untuk mengetahui keabsahan sebuah penelitian, dengan menggunakan berbagai teknik pula. Peneliti menggunakan metode penelitian kepustakaan (library research). Penelitian kepustakaan merupakan penelitian yang dilakukan di perpustakaan mengambil setting perpustakaan sebagai tempat penelitian dengan objek penelitian adalah bahan-bahan kepustakaan, penelitian berhadapan dengan berbagai literatur sesuai dengan tujuan dan masalah yang akan dan sedang diteliti. Hasil dari penelitian ini adalah cara menjadi investor; menyiapkan data diri, mendaftar ke perusahaan sekuritas, mulai investasi saham. implementasi ekonomi syariah investasi saham halal ditunujukkan dengan adanya anjuran Al-qur'an surat yusuf (46-49), hadits, fatwa DSN-MUI serta perkembangan yang luar biasa pada investasi saham syariah.

Kata Kunci: ekonomi syariah, investasi, saham syariah

\footnotetext{
${ }^{1}$ Dosen STAIMA Cirebon, Prodi Hukum Ekonomi Syariah
} 


\section{PENDAHULUAN}

Penerapan ekonomi syariah telah dikembangkan pada berbagai bidang tidak hanya pada bidang perdagangan tradisional saja dimana adanya transaksi manual antara penjual dan pembeli kemudian melakukan transaksi dalam perkembangannya ekonomi islam telah bertransformasi secara luas termasuk dalam kegiatan pasar modal. Pasar modal syariah telah berkembang dengan baik mulai dari tahun 2011 sampai dengan sekarang. Pasar modal syariah bertujuan untuk menghubungkan pihak-pihak yang mempunyai kelebihan dana dan orang-orang atau lembaga yang membutuhkan dana dengan cara menerbitkan produk investasi yang tentu saja dengan aturan-aturan yang sesuai dengan syariah Islam yaitu yang bersumber pada Al-qur'an dan hadits.

Pasar modal merupakan sarana untuk menjalankan fungsi intermediasi yaitu sebagai wadah dalam kegiatan ekonomi islam di bidang pasar modal (saham, reksadana, obligasi, sukuk dan lain-lain) bagi pihak-pihak yang membutuhkan dan memerlukan dana dengan membeli berbagai produk investasi di pasar modal. Proses intermediasi tersebut tidak hanya harus menguntungkan namun juga harus dilakukan sesuai dengan syariah Islam. Perkembangan pasar modal syariah merupakan pasar modal yang seluruh aktivitasnya berdasarkan syariah Islam artinya seluruh kegiatannya sesuai dengan aturan yang berlandaskan landasan hukum dalam Al-qur'an dan hadits. Kegiatan-kegiatan tersebut termasuk penggunaan akad transaksinya, produk yang dihasilkan oleh sebuah perusahaan, pendapatan kotor dan bersih sebuah perusahaan berdasarkan laporan keuangan yang dikeluarkan oleh perusahaan tersebut, kinerja perusahaan, tentang fatwa-fatwa, juga produk atau efek dari pasar modal syariah.

Era distrupsi merupakan era "kekacauan" yang bisa mewakili istilah jaman sekarang dalam dimensi budaya, era digital dalam dimensi teknologi, era revolusi industri dalam dimensi perubahan alat dan merode. Distrupsi dimaknai oleh perubaan-perubahan perilaku hidup serta cara pandang, alat yang digunakan dan pekerjaan yang terdampak dan adanya kecenderungan-kecenderungan perubahan yang benar-benar baru. ${ }^{2}$ Investasi saham syariah merupakan salah satu dari sekian banyak bidang yang harus menyesuaikan dengan perkembangan zaman. Jika dahulu kita berinvestasi masih menggunakan cara-cara "old" seperti investasi itu berupa emas, tanah atu properti namun demikian cara tersebut masih banyak digunakan namun saat ini mulai berkembang dengan invetasi di pasar modal seperti saham, obligasi, sukuk, reksadana dan lain-lain.

Investasi berupa saham sudah banyak diperkenalkan kepada masyarakat. Literasi investasi saham syariah sudah banyak dilakukan seperti sudah banyak sekolah pasar modal level 1 dan level 2, literasi pasar modal oleh OJK, tumbuhnya galeri investasi di universitas atau bahkan galeri investasi desa (dengan program desa menabung saham). literasi investasi

${ }^{2}$ Dini Selasi, Moderasi Islam Di Era Distrupsi Dalam Pandangan Kearifan Lokal, Pendidikan Islam, Ekonomi Syariah, Fenomena Sosial Keagamaan (Yogyakarta: Gading Pustaka, 2018). 
saham sudah banyak dan mudah diakses melalui sistem online. Perkembangan ekonomi syariah di Indonesia sering sekali identik dengan hanya perbankan syariah karena perkembangan perbankan syariah yang sangat luar biasa, namun demikian investasi syariah juga sebagian dari perkembangan ekonomi syariah di Indonesia. Perkembangan perbankan syariah akan sealalu berkaitan dan berhubungan dengan investasi saham syariah, perbankan syariah sebagai sarana untuk transaksi investasi saham sebagai sarana penyimpanan dan pengambilan dana.

Investasi saham merupakan bagian dari produk investasi syariah yang ada di pasar modal syariah. Literasi yang sudah cukup bagus dilakukan oleh pihak-pihak yang berwenang seperti OJK, Pasar Modal Syariah (IDX Islamic), Galeri Investasi dan lain-lain. Dengan penulisan jurnal ini diharapkan akan menjadi salah satu kajian literasi bagi yang ingin megetahui tentang investasi pasar modal syariah khususnya tentang investasi saham syariah.

Berdasarkan latar belakang teresebut diatas, dalam penulisan jurnal ini akan mengambil rumusan masalah sebagai berikut : Bagaimana cara menjadi investor saham syariah ? Bagaimana implementasi ekonomi syariah pada investasi syariah? Bagaimana perkembangan investasi saham syariah di Indonesia?

\section{METODE PENELITIAN}

Peneliti menggunakan metode penelitian kepustakaan (library research). Penelitian kepusatakaan merupakan penelitian yang dilakukan di perpustakaan mengambil setting perpustakaan sebagai tempat penelitian dengan objek penelitian adalah bahan-bahan kepustakaan, penelitian berhadapan dengan berbagai literatur sesuai dengan tujuan dan masalah yang akan dan sedang diteliti. Penelitian ini menghasilkan kesimpulan tentang kecenderungan sebuah teori yang digunakan dari waktu ke waktu, perkembangan paradigma dan pendekatan ilmiah pengetahuan tertentu. ${ }^{3}$

Penelitian kepustakaan merupakan metode yang digunakan dalam pencarian data atau observasi secara mendalam terhadap tema yang diteliti untuk menemukan jawaban sementara' dari masalah yang ditemukan diawal sebelum penelitian ditindaklanjuti, merupakan metode dalam pencarian, mengumpulkan dan menganalisa sumber data untuk diolah dan disajikan dalam bentuk laporan penelitian kepustakaan berdasarkan atas karya tulis termasuk penelitian yang belum atau yang sudah di publikasikan. Penelitian kepustakaan merupakan kajian literatur yaitu penelusuran penelitian terdahulu untuk ditindaklanjuti dan membuat gagasan baru untuk mengembangkan teori atau sebagai penambahan penelitian baru yang didukung oleh data-data dari sumber pustaka.

Penelitian kepustakaan atau studi pustaka merupakan kegiatan dengan metode pengumpulan data pustaka, membaca dan mencatat serta mengolah bahan penelitian,

3 Burhan Bungin, Penelitian Kualitatif: Komunikasi, Ekonomi, Kebijakan Publik, Dan IImu Sosial Lainnya, Jakarta: Kencana, 2011 <https://doi.org/10.1002/jcc.21776>. 
menurut Mestika Zed ${ }^{4}$ ada beberapa alasan mengapa penelitian menggunakan studi pustaka dan langkah-langkah untuk melakukan penelitian kepustakaan yaitu; penelitian ini hanya bisa dijawab dengan studi pustaka; sebagai tahap tersendiri yaitu studi pendahuluan untuk memahami lebih dalam gejala baru yang telah berkembang di lapangan atau yang ada di masyarakat; misalnya seorang dokter akan melihat buku-buku tentang sifat dan jenis virus, jika mungkin ada penyakit yang sedang terjangkit di masyarakat; data pustaka tetap handal untuk menjawab persoalan penelitian: misalnya riset yang dilakukan orang lain dan berasal dari laporan-laporan resmi.

\section{PEMBAHASAN}

Jika kita lihat hasil analisa jangka panjang maupun jangka pendek maka potensi pasar modal syariah dinilai baik dan masih akan mengalami pertumbuhan, hal ini terlihat dari hasil return indeks JII yang lebih baik dari indeks IHSG hal ini berhubungan dengan adanya kebijakan pemerintah yang membentuk Komite Nasional Keuangan Syariah (KNKS). Pasar modal syariah ini merupakan salah satu instrumen ekonomi yang dibutuhkan negara Indonesia dalam membantu pembangunan yang dilakukan oleh pemerintah ataupun swasta ${ }^{5}$.

Dalam konsep pasar, ada 4 syarat yang harus dipenuhi agar bisa disebut pasar. 4 syarat tersebut diantaranya: penjual, pembeli, barang yang diperjual-belikan (produk), tawar menawar. Di pasar tradisional, 4 syarat tersebut sudah terpenuhi, sehingga disebut pasar. Pasar modal syariah memiliki konsep yang sama persis dengan konsep pasar trandisional. Penjual adalah perusahaan sekuritas yang akan memperdagangkan produk (efek) yang diterbitkan oleh perusahaan (emiten). Pembeli adalah para investor yang akan membeli efek perusahaan dari sekuritas. Namun demikian, investor di pasar modal syariah bisa menjadi pembeli dan menjadi penjual. Sebagai pembeli, investor akan meminta kepada perusahaan sekuritas untuk mencarikan efek yang diinginkan. Sebagai penjual, investor akan meminta pula kepada sekuritas untuk menjualkan efeknya. Transaksi saham pasar modal syariah menggunakan mekanisme tawar-menawar yang berlangsung secara terus menerus selama periode perdagangan atau (Bai'al musawamah). Produk yang diperjual-belikan di pasar modal syariah adalah berupa surat berharga atau efek. Diantaranya saham, sukuk, dan reksadana. ${ }^{6}$

\footnotetext{
${ }^{4}$ Mustika Zed, Metode Penelitian Kepustakaan (Jakarta: Yayasan Obor Indonesia, 2008).

${ }^{5}$ Qoonitah Fithri Al-Nisa, 'PERBANDINGAN ANTARA RETURN SAHAM SYARIAH DAN SAHAM KONVENSIONAL DI BURSA EFEK INDONESIA (PENDEKATAN VEKTOR ERROR CORRECTION MODEL)', INKLUSIF (JURNAL PENGKAJIAN PENELITIAN EKONOMI DAN HUKUM ISLAM), 3.2 (2018), 147-55.

6 Akucintakeuangansyariah.com, 'Mengenal Investasi Yang Amanah: Pasar Modal Syariah', 2019 <www.akucintakeuangansyariah.com/mengenalinvestasiyangamanahpasarmodalsyariah> [accessed 21 March 2019].
} 


\section{A. Cara Menjadi Investor Saham Syariah}

Proses untuk membuka rekening saham terbilang cukup sederhana. Sebelum kita mencoba membuka rekening saham, ada beberapa syarat yang perlu kita siapkan untuk dapat membuka rekening saham, antara lain ${ }^{7}$ :

1. ID Card: KTP/KITAS/Passport, Sementara bagi WNA, maka syarat KITAS/Passport menjadi syarat wajib juga.

2. NPWP juga menjadi syarat wajib saat pembukaan rekening efek.

3. Cover Buku Tabungan juga termasuk salah satu syaratnya.

4. No Identitas KSEI.

5. Fotokopi KTP suami, fotokopi NPWP suami, dan juga fotokopi Kartu Keluarga biasanya juga perlu disertakan bila pekerjaan Anda adalah seorang Ibu Rumah Tangga.

6. Meterai Rp6.000, Anda dapat sediakan uang untuk membeli meterai. Meterai yang dibutuhkan antara 2-8 meterai, bergantung pada kebutuhan Anda.

Trading saham bisa dilakukan secara online yang disebut syariah online trading system (SOTS) sistem transaksi saham syariah secara online yang memenuhi prinsipprinsip syariah di pasar modal.

SOTS dikembangkan oleh anggota bursa sebagai fasilitas atau alat bantu bagi investor yang ingin melakukan transaksi saham secara syariah. SOTS disertifikasi oleh DSN-MUI karena merupakan penjabaran dari fatwa DSN-MUI No. 80 tahun 2011 tentang Penerapan Prinsip Syariah Dalam Mekanisme Perdagangan Efek Bersifat Ekuitas Di Pasar Reguler Bursa Efek. Fitur utama SOTS adalah sebagai berikut: ${ }^{8}$

1. Hanya saham syariah yang dapat ditransaksikan.

2. Transaksi beli saham syariah hanya dapat dilakukan secara tunai (cash-basis transaction) sehingga tidak boleh ada transaksi margin (margin trading).

3. Tidak dapat melakukan transaksi jual saham syariah yang belum dimiliki (short selling).

4. Laporan kepemilikan saham syariah dipisah dengan kepemilikan uang sehingga saham syariah yang dimiliki tidak dihitung sebagai modal (uang).

${ }^{7}$ Haris Darmawan, 'Bagaimana Cara Membuka Rekening Saham Dan Mulai Membeli Saham', 18 April, 2017 $<w w w$. Financialku.com> [accessed 14 March 2019].

8 IDX Islamic, 'Syariah Online Trading System', IDX Islamic, 2018 <https://www.idx.co.id/idx-syariah/transaksisesuai-syariah> [accessed 14 March 2019]. 
Tabel 1. Anggota Bursa yang telah memiliki SOTS

\begin{tabular}{|c|c|c|c|}
\hline No & Anggota Bursa & Nama SOTS & Alamat Website (Link) \\
\hline 1 & $\begin{array}{l}\text { PT Indo Premier } \\
\text { Securities }\end{array}$ & IPOT Syariah & www.indopremier.com \\
\hline 2 & $\begin{array}{l}\text { PT Mirae Asset Sekuritas } \\
\text { Indonesia }\end{array}$ & HOTS Syariah & www.miraeasset.co.id \\
\hline 3 & PT BNI Securities & e-Smart Syariah & www.bnisekuritas.co.id \\
\hline 4 & $\begin{array}{l}\text { PT Trimegah Securities } \\
\text { Tbk. }\end{array}$ & iTrimegah Syariah & www.trimegah.com \\
\hline 5 & PT Mandiri Sekuritas & MOST Syariah & www.most.co.id \\
\hline 6 & PT Panin Sekuritas Tbk. & POST Syariah & https://pans.id/ \\
\hline 7 & PT Phintraco Securities & PROFITS Syariah & www.profits.co.id \\
\hline 8 & PT Sucorinvest & SPOT Syariah & $\begin{array}{l}\text { https://sucorsekuritas. } \\
\text { com/ }\end{array}$ \\
\hline 9 & PT First Asia Capital & FAST Syariah & www.facsekuritas.co.id \\
\hline 10 & PT MNC Securities & $\begin{array}{ll}\text { MNC } & \text { Trade } \\
\text { Syariah } & \end{array}$ & www.mncsekuritas.id \\
\hline 11 & PT Henan Putihrai & HPX Syariah & $\begin{array}{l}\text { www.henanputihrai.co } \\
\text { m }\end{array}$ \\
\hline
\end{tabular}




\begin{tabular}{|c|l|l|l|}
\hline No & Anggota Bursa & Nama SOTS & Alamat Website (Link) \\
\hline 12 & PT Philip Sekuritas & POEM Syariah & www.phillip.co.id \\
\hline 13 & PT RHB Sekuritas & RHB TradeSmart & $\begin{array}{l}\text { https://rhbtradesmart. } \\
\text { co.id/ }\end{array}$ \\
\hline
\end{tabular}

Secara garis besar tujuan utama orang masuk ke pasar modal berbeda-beda misalnya ada yang berharap sesuatu yang lebih jika masuk pasar modal, ada yang ingin membuat tabungan jangka panjang, ada yang ingin mengembangkan uangnya dari pada ditabung secara biasa atau disimpan melalui deposito, ada yang hanya iseng-iseng bahkan ada pula yang menjadikan pekerjaan utama atau disebut trading for life. Tujuan setiap orang akan berbeda, begitupun akan berpengaruh pada strategi yang akan diambil dalam berinvestasi saham yang akan berpengaruh pada pengambilan atau pembelian saham yang berbeda pula.

Strategi di pasar modal tidak ada strategi yang khusus dalam pembenaran atau salah yang paling cocok atau tidak cocok dimana semuanya akan menyesuaikan dengan karakter pribadi dengan tujuan masing-masing pribadi seorang investor bahkan katakan jika memilih saham yang sama pun akan mempunyai strategi yang berbeda pula yang disesuaikan dengan tujuan pribadi masing-masing. Secara garis besar penyesuaian strategi dengan tujuan berinvestasi di pasar modal dapat dibedakan menjadi : investasi jangka panjang ; minimal 3 tahun, investsasi jangka menengah ; minimal 1-2 bulan, investasi jangka pendek ; 1-5 hari, trading harian. Semua tujuan, akan disesuaikan dengan keinginan dan karakter serta kepentingan masing-masing individu karena setiap jenis investasi mempunyai karakter, strategi, teknik serta pemilihan saham yang berbeda pula.

\section{B. Implementasi Ekonomi Syariah pada Investasi Saham Syariah}

Ekonomi Islam merupakan cabang ilmu yang mempelajari metode untuk memahami dan memecahkan masalah ekonomi yang didasarkan atas ajaran agama Islam karena merupakan bagian yang tak terpisahkan dari agama Islam. Dimana Islam telah menyediakan berbagai perangkat aturan lengkap bagi kehidupan manusia, termasuk bidang ekonomi, beberapa aturan bersifat pasti dan berlaku permanen namun beberapa bersifat kontekstual sesuai dengan situasi dan kondisi. ${ }^{9}$

Saham syariah merupakan efek berbentuk saham yang tidak bertentangan dengan prinsip syariah di Pasar Modal. Definisi saham dalam konteks saham syariah merujuk kepada definisi saham pada umumnya yang diatur dalam undang-undang maupun peraturan OJK

\footnotetext{
${ }^{9}$ P3El. Pusat Pengkajian dan Pengembangan Ekonomi Islam, Ekonomi Islam (Jakarta: Rajawali, 2013).
} 
lainnya. Ada dua jenis saham syariah yang diakui di pasar modal Indonesia. Pertama, saham yang dinyatakan memenuhi kriteria seleksi saham syariah berdasarkan peraturan OJK no. II.K.1 tentang penerbitan Daftar Efek Syariah, kedua adalah saham yang dicatatkan sebagai saham syariah oleh emiten atau perusahan publik syariah berdasarkan peraturan OJK no. 17/POJK.04/2015. Semua saham syariah yang terdapat di pasar modal syariah Indonesia, baik yang tercatat di BEI maupun tidak, dimasukkan ke dalam Daftar Efek Syariah (DES) yang diterbitkan oleh OJK secara berkala, setiap bulan Mei dan November. ${ }^{10}$

Konsep investasi menurut pandangan Islam berbeda dengan investasi ekonomi non muslim, perbedaan ini terjadi terutama karena pengusaha Islam tidak menggunakan tingkat bunga dalam menghitung investasi. Di mana harta atau uang dinilai oleh Allah sebagai Qiyaman, yaitu sarana pokok kehidupan. Investasi yang berarti menunda pemanfaatan harta yang kita miliki pada saat ini, atau berarti menyimpan, mengelola dan yang dianjurkan dalam al-Qur'an seperti yang dijelaskan dalam surat Yusuf ayat $46-49^{11}$.

Saham merupakan bukti kepemilikan suatu perusahaan. Konsep saham merupakan konsep kegiatan musyarakah/syirkah, yaitu penyertaan modal dengan hak bagi hasil usaha. Dengan demikian, saham tidak bertentangan dengan prinsip syariah, karena saham merupakan bukti penyertaan modal dari investor kepada perusahaan, yang kemudian investor akan mendapatkan bagi hasil berupa deviden. Namun demikian, tidak semua saham dapat langsung dikategorikan sebagai saham syariah, ada beberapa hal yang harus diperhatikan dalam kategori saham sayriah yaitu: ${ }^{12}$

1. Business Screening; kegiatan perusahaan yang mengeluarkan saham syariah tidak melakukan perjudian, perdagangan yang dilarang, jasa keuangan ribawi, jual beli resiko yang mengandung gharar (ketidakpastian), maysir (perjudian), menghasilkan produksi barang haram, menerima suap (risywah).

2. Financial Screening; total utang berbasis bunga dibandingkan dengan total aset tidak lebih dari $45 \%$, pendapatan non halal dibanding total pendapatan tidak lebih dari $10 \%$.

3. Daftar Efek Syariah (DES); emiten atau perusahaan yang terdaftar di IHSG (Indeks Saham Gabungan) di Indonesia tidak semua emiten bisa masuk dalam daftar DES. Daftar Efek Syariah (DES) adalah kumpulan efek yang tidak bertentangan dengan prinsip syariah di pasar modal, yang ditetapkan oleh OJK atau pihak yang mendapat persetujuan dari OJK sebagai Pihak Penerbit DES. Pihak yang dapat menerbitkan Daftar Efek Syariah selain OJK (Pihak Penerbit DES), adalah pihak yang telah mendapatkan persetujuan dari OJK untuk menerbitkan DES yang berisi efek syariah yang tercatat di Bursa Efek luar negeri. Pihak yang dapat menjadi Pihak Penerbit DES

10 IDX Islamic, 'Produk Syariah', IDX Islamic, $2018<$ http://www.idx.co.id/idx-syariah/produk-syariah> [accessed 15 November 2018].

${ }^{11}$ Anna Nurlita, 'Investasi Di Pasar Modal Syariah Dalam Kajian Islam', Kutubkhanah, 17.1 (2015), 1-20.

12 OJK, 'Pasar Modal Syariah', OJK, 2017 <https://www.ojk.go.id/id/kanal/syariah/tentangsyariah/pages/pasar-modal-syariah.aspx> [accessed 14 March 2019]. 
yaitu pihak yang mendapat persetujuan dari OJK untuk menerbitkan DES, manajer Investasi syariah, manajer Investasi yang memiliki Unit Pengelolaan Investasi syariah.

\section{Perkembangan Investasi Saham Syariah di Indonesia}

Irwan Abdalloh dalam bukunya 'Pasar Modal Syariah'13 menerangkan bahwa pertumbuhan pasar modal syariah secara resmi diawali dengan terbitnya UU RI No.8 Tahun 1995 tentang pasar modal. Keberadaan UU ini menjadi pemicu muncunya produk investasi di pasar modal. Secara garis besar sejarah perkembangan pasar modal syariah dibagi dalam dua bagian, yaitu kelahiran pasar modal Islam Indonesia pada tahun 1997 dan bagian ke dua kebangkitan pasar modal syariah Indonesia yang diawali dengan peluncuran indeks saham syariah Indonesia (ISSI) pada tahun 2011.

\section{Tonggak kelahiran pasar modal syariah Indonesia}

a. Tahun 1997; merupakan lahirnya pasar modal syariah Indonesia yang diawali dengan penerbitan reksa dana syariah pertama di Indonesia oleh Danareksa Investment Management (DIM) pada tahun 1997. Sementara iti reksa dana syariah pertama kali diluncurkan di dunia oleh The Amana Income Funds pada tahun 1986 di Indianapilis, Amerika Serikat.

b. Tahun 1999; Majelis Ulama Indonesia (MUI) mendirikan Dewan Syariah Nasional (DSN) - Majelis Ulama Indonesia (MUI) pada tahun 1999, sebagai lembaga independen di bawah MUI yang bertanggung jawab terhadap fatwa terkait ekonomi Islam di Indonesia.

c. Tahun 2000; Danareksa Investment Management (DIM) bekerjasama dengan Bursa Efek Indonesia (BEI) meluncurkan Jakarta Islamic Index (JII) sebagai indeks saham syariah pertama di Indonesia pada tahun 2000. JII adalah indeks saham syariah yang terdiri dari 30 saham syariah yang paling liquid di Indonesia. Pada awalnya seleksi saham syariah yang termasuk JII dilakukan oleh DIM sedangkan kriteria saham liquid di susun oleh BEl. Peluncuran JII hanya berselang satu tahun dari penerbitan indeks saham syariah pertama di dunia, Dow Jones Islamic Market Indeks (DJIM) pada tahn 1999.

d. Tahun 2001; DSN - MUI menerbitkan Fatwa no.20 Tahun 2001 tentang pedoman pelaksanaan investasi untuk reksa dana syariah. fatwa ini menjadi fatwa pertama yang dikeluarkan oleh DSN-MUI terkait pasar modal Islam dan merupakan respon dari diluncurkannya reksa dana syariah pertama di tahun 2000.

e. Tahun 2002; PT Indosat menerbitkan obligasi syariah pertama di Indonesia dengan menggunakan akad mudharabah pada tahun 2002. Andalan Artha Advisiondo (AAA) sekuritas menjadi penjamin emisi dari produk tersebut. Pada saat itu, regulasi tentang Sukuk belum ada sehingga digunakan istilah obligasi syariah agar tidak melanggar peraturan yang berlaku. Pada tahun 2017; izin usaha AAA sekuritas

\footnotetext{
${ }^{13}$ Abdalloh.
} 
dicabut oleh OJK karena terbukti melakukan pelanggaran regulasi pasar modal Indonesia. DSN-MUI menerbitkan fatwa yang digunakan sebagai dasar kesesuaian prinsip Islam dan obligasi syariah mudharabah PT. Indosat, yaitu fatwa no. 32 tahun 2002 tentang obligasi syariah dan fatwa no. 33 tahun 2002 tentang obligasi syariah mudharabah.

f. Tahun 2003; DSN-MUI menerbitkan fatwa no.40 tahun 2003 tentang pasar modal dan pedoman umum penerapan prinsip syariah di bidang pasar modal. Ada sebagian kalangan yang menjadikan peluncuran fatwa sebagai indikator pendirian pasar modal syariah Indonesia.

g. Tahun 2004; PT Matahari Putra Prima (MPP) menerbitkan obligasi syariah ijarah pertama di Indonesia pada tahun 2004. Fatwa no.41 tahun 2004 DSN-MUI tentang obligasi syariah ijarah sebagai dasar kesesuaian prinsip syariah Islam dari obligasi syariah ijarah MPP.

h. Tahun 2006; Bapepam-LK mengeluarkan regulasi tentang pasar modal syariah pertama di Indonesia pada tahun 2006, terdiri dari; Peraturan No.IX.A.13 tentang penerbitan efek syariah. Peraturan No.IX.A.14 tentang akad-akad yang digunakan dalam penerbitan efek syariah di pasar modal. Sejak dikeluarkannya regulasi tentang efek syariah ini, maka istilah obligasi syariah secara resmi diganti dengan sukuk.

i. Tahun 2007; Bapepam-LK menerbitkan peraturan II.K.1 tentang kriteria dan penerbitan daftar efek syariah (DES) pada tahun 2007. Berdasarkan regulasi ini saham syariah yang masuk JII tidak lagi diseleksi oleh DIM tetapi mengikuti DES yang diterbitkan OJK setiap enam bulan sekali.

j. Tahun 2008; Pemerintah Indonesia membuat UU no.19 Tahun 2008 tentang Surat Berharga Syariah Negara (SBSN) yang lebih dikenal dengan Sukuk Negara. DSN-MUI menerbitkan empat fatwa sekaligus sebagian dasar kesesuaian prinsip syariah dari penerbitan sukuk negara pada tahun 2008. Fatwa tersebut adalah; Fatwa no. 69 tentang SBSN, fatwa No. 70 tentang Metode Penerbitan SBSN, fatwa No.71 tentang sale and lease back, fatwa no 72 tentang SBSN ijarah sale and lease back.

k. Tahun 2010 ; Bursa Efek Indonesia menyelenggarakan edukasi pasar modal syariah pertama kali pada tahun 2010 dengan menggunakan merek Sekolah Pasar Modal Syariah (SPMS) pada tahun 2010 yang bekerjasama dengan MES (Masyarkat Ekonomi Syariah).

\section{Tonggak Kebangkitan Pasar Modal Syariah Indonesia}

a. Tahun 2011; BEI menerbitkan Indeks Saham Syariah Indonesia (ISSI) pada mei 2011. ISSI adalah indeks komposit seluruh saham syariah yang tercatat di BEI, ISSI diterbitkan oleh BEI sebagai respons dari adanya kebutuhan pasar tentang indeks pembanding yang menggambarkan kinerja seluruh saham syariah di Indonesia. Seluruh saham ISSI tercatat dalam dalam DES. DSN-MUI menerbitkan fatwa no.80 
thun 2011 tentang prinsip syariah dalam mekanisme perdagangan efek bersifat ekuitas di pasar reguler bursa efek sebagai respons dari permintaan BEI untuk dasar kesesuaian prinsip Islam dalam transaksi saham syariah di BEI. BEI memperkenalkan model bisnis Sharia Online Trading System (SOTS) pada tahun 2011 sebagai alat bantu transaksi bagi investor yang ingin melakukan perdagangan saham syariah yang sesuai dengan prinsip Islam. PT Indo Premire Sekuritas mengembangkan SOTS untuk pertama kalinya di Indonesia pada September 2011.

b. Tahun 2013 ; Bank Syariah mandiri menjadi Bank RDN Syariah pertama di Indonesia pada tahun 2013. Keberadaan RDN syariah adalah sebagai respons fatwa DSN-MUI no.80 yang mensyaratkan seluruh proses bisnis saham syariah harus memenuhi prinsip Islam. PT Indo Premire Sekuritas menerbitkan produk Exchange Traded Funds (ETF) syariah pertama di Indonesia tahun 2013. ETF syariah menggunakan JII sebagai indeks dasar penerbitannya.

c. Tahun 2014 ; Bank Panin Syariah menjadi emiten syariah pertama yang tercatat di BEI pada tahun 2014. Pada tahun 2017 berubah namanya menjadi Bank Panin Dubai Syariah setelah Dubai Islamic Bank masuk menjadi pemegang saham.

DSN-MUI menerbitkan fatwa no.95 tentang SBSN wakalah sebagai dasar kesesuaian prinsip Islam dari penerbitan SBSN dengan menggunakan akad wakalah.

d. Tahun 2015 ; Universitas Islam Indonesia (UII) bekerjasama dengan BEI dan Phintraco Sekuritas mendirikan Galeri Investasi Syariah (GIS) pertama di Indonesia tahun 2015.

e. Tahun 2016 ; BEI memperoleh penghargaan sebagai The Best Supporting Institution of the year 2016 dari GIFA (Global Islamic Finance Award). BEl diakui sebagai perusahaan yang aktif mendorong perkembangan pasar modal syariah Indonesia.

f. Tahun 2017 ; Henan Puthirai Sekuritas bekerjasama dengan Badan Amil Zakat Nasional (BAZNAS) meluncurkan zakat saham pada tahun 2017. Zakat saham adalah inovasi yang menggabungkan filantropi Islam dengan investasi di pasar modal, dimana yang saham menjadi objek infak, sedekah dan zakat. BEI memperoleh penghargaan sebagai The Best Supporting Institution of the year 2017 dari GIFA (Global Islamic Finance Award). BEl diakui sebagai perusahaan yang aktif mendorong perkembangan pasar modal syariah Indonesia.

\section{Perkembangan Investasi Saham Syariah di Indonesia}

Indeks saham syariah Indonesia mencatatkan pertumbuhan $20 \%$ year to date per 20 September 2016. Menjadi pertumbuhan tertinggi, dibandingkan dengan indeks saham syariah global lainnya, Head of Islamic Capital Market Development Bursa Efek Indonesia Irwan Abdalloh menuturkan dalam lima tahun terakhir, indeks saham syariah Indonesia (ISSI) tumbuh 43\%, sedangkan indeks hargsa saham gabungan (IHSG) sebesar $41 \%$. Pertumbuhan aset pasar modal syariah menunjukkan pertumbuhan negatif dalam dua tahun terakhir, yakni terkoreksi 2,3\% dari posisi US\$370,5 miliar pada 2014 menjadi 
US\$361,9 miliar pada 2015. Sementara itu, ISSI tumbuh hingga 20\%," ungkapnya saat pelatihan wartawan pasar modal. Adapun jumlah investor syariah di Indonesia masih mencapai 8.580 investor pada Juli 2016. Sementara itu, kapitalisasi pasar syariah per 26 September 2016 mencapai Rp3.228 triliun, sedangkan kapitalisasi pasar saham mencapai Rp5.776 triliun. Irwan Abdalloh mengungkapkan untuk meningkatkan kapitalisasi pasar modal syariah maka pihaknya melakukan sekolah pasar modal syariah (SPMS), syariah online trading system (SOTS), galeri investasi syariah dan sekolah pasar modal syariah $(\mathrm{SPMS})^{14}$.

Menurut Kepala Divisi Pasar Modal Syariah BEI, Irwan Abdalloh dalam peluncuran bukunya yang berjudul 'Pasar Modal Syariah' jumlah investor pasar modal yang tercatat melalui nomor tunggal identitas investor atau single investor identification (SID) yang diterbitkan oleh Kustodian Sentral Efek Indonesia (KSEI) baru mencapai 1,61 juta orang dan hanya 50.000 diantaranya yang terdeteksi sebagai investor syariah. BEI masih terus menggenjot inkulsi dan literasi pasar modal lewat komunitas yang dinilai peran penting. "Kami menggandeng berbagai komunitas untuk umum kami mengajak Masyarakat Ekonomi Syariah (MES), akademisi kami ajak Ikatan Ahli Ekonomi Islam Indonesia (IAEI), mahasiswa kami ajak Forum Silaturahim Studi Ekonomi Islam (FoSSEI), investor muda ada Komunitas Investor Saham Pemula (ISP), ibu-ibu muda kami gandeng Fatayat Nahdatul Ulama (NU) dan komunitas hijabers, pemuda kami ajak GP Anshor dan Himpunan Mahasiswa Islam (HMI), kami ajak juga Ustadz dan lembaga dakwah ${ }^{15}$.

Saat ini market share sebesar 5,2 persen padahal target pada 2021 sebesar 5 persen. Pada 2018 target itu sudah tercapai, trading value saat ini sebesar Rp 1,9 triliun dalam setahun. Adapun pada akhir 2018, kata Irwan, jumlah investor pasar modal syariah sebanyak 44 ribu, angka tersebut sebanding dengan 5,2 persen dari total investor pasar modal. Pertumbuhan investor syariah di 2018, itu growth-nya 92\%, kita mengalahkan growth 2017 yang naik 75\%, dengan jumlah investor syariah 5,2\% terhadap total investor, ini luar biasa karena target 2020 sudah dicapai. Pada akhir 2019, Irwan yakin bisa mencapai 100 ribu investor. "Sekarang investor syariah 50 ribuan. Akhir tahun bisa 100 ribu saja sudah luar biasa ${ }^{16}$.

Berdasarkan data Kustodian Sentral Efek Indoensia (KSEI) ada beberapa informasi tentang jumlah investor, Single Investor Identification (SID) juga penyebaran investor secara demografi

Tabel 2. Jumlah Investor tahun 2018

\footnotetext{
${ }^{14}$ Novita Sari Simamora, 'Indeks Saham Syariah Indonesia Tumbuh Tertinggi Di Dunia', Financialbisnis.Com, 2016.

${ }^{15}$ Rezha Hadyan, 'Ini Strategi BEI Menggenjot Investor Saham Syariah Indonesia', Kontan.Co.Id, 2019 <https://investasi.kontan.co.id/news/ini-strategi-bei-menggenjot-investor-saham-syariah-di-indonesia> [accessed 13 February 2019].

${ }^{16}$ Muhammad Hendartyo, 'BEI Bidik 100 Ribu Investasi Saham Syariah 2019', Bisnis.Tempo.Co (Jakarta, 9 February 2019).
} 


\begin{tabular}{|l|l|}
\hline \multicolumn{1}{|c|}{ Usia Investor } & \multicolumn{1}{c|}{ Jumlah Investor } \\
\hline Usia 21-30 Tahun & $39,72 \%$ \\
\hline Usia 31-40 Tahun & $25,34 \%$ \\
\hline Usia 41-50 Tahun & $18,69 \%$ \\
\hline Usia 51-60 Tahun & $10,69 \%$ \\
\hline Usia > 60 & $5,56 \%$ \\
\hline
\end{tabular}

Menurut Direktur Utama KSEI Friderica Widyasari Kustodian Sentral Efek Indonesia (KSEI) mencatatkan, generasi milenial berusia 21-30 tahun mendominasi investor ritel di pasar modal Indonesia. Persentase investor muda pada penghujung tahun 2018 ini mencapai 39,72\% dari total investor pasar modal yang berjumlah 1,6 juta investor, atau sekitar 635.000 investor. Sementara itu, investor yang berusia 31-40 tahun mencapai $25,34 \%$ dari total investor, investor berusia 41-50 tahun mencapai 18,69\%, investor berusia 51-60 tahun 10,69\%, dan investor berusia di atas 60 tahun 5,56\%. Investor tersebut terdiri dari investor saham, surat utang, reksa dana, surat berharga (SBSN), serta efek lainnya yang tercatat di KSEI. Jumlah tersebut mengalami peningkatan yang signifikan dibandingkan kondisi pada $2017^{17}$.

Tabel 3. Tabel Single Investor Identification (SID)

\begin{tabular}{|c|c|}
\hline Jenis SID & Jumlah SID \\
\hline Saham & 851 ribu \\
\hline Reksadana & 988 ribu \\
\hline SBN & 195 ribu \\
\hline
\end{tabular}

Gencarnya sosialisasi yang dilakukan pihak self regulatory organization (SRO) bursa juga mampu menjaring banyak investor muda. Pihak SRO bursa banyak melakukan sosialisasi di kampus-kampus sehingga ada sekitar 300 galeri investasi di seluruh Indonesia yang menarik, dari sekitar 1,6 juta investor berdasarkan informasi single investor identification (SID), 851 ribu SID memiliki instrumen saham, 988 SID memiliki reksa dana, dan 195 ribu SID memiliki SBN. Artinya, satu SID atau investor tidak hanya berinvestasi pada satu instrumen saja, tetapi juga berinvestasi di instrumen lainnya.

Tabel 3 Penyebaran investor di Indonesia

\begin{tabular}{|c|c|}
\hline Pulau di Indonesia & Jumlah Investor \\
\hline Jawa & $2.118 \mathrm{~T}$ \\
\hline
\end{tabular}

17 Ihya Ulum Aldin, 'Investor Melenial Semakin Mendominasi Pasar Modal', Katadata.Co.Id, 2018 <https://katadata.co.id/berita/2018/12/27/investor-milenial-semakin-mendominasi-pasar-modal> [accessed 18 March 2019]. 


\begin{tabular}{|c|c|}
\hline Sumatera & $33,68 \mathrm{~T}$ \\
\hline Kalimantan & $46,51 \mathrm{~T}$ \\
\hline Sulawesi & $4,26 \mathrm{~T}$ \\
\hline Bali - NTT & $3,45 \mathrm{~T}$ \\
\hline Maluku - Papua & $1,27 \mathrm{~T}$ \\
\hline
\end{tabular}

Sementara itu, persebaran investor secara demografi masih terpusat di Pulau Jawa dengan total aset investor mencapai $\mathrm{Rp} 2.118$ triliun, Sumatera $\mathrm{Rp}$ 33,68 triliun, Kalimantan Rp 46,51 triliun, Sulawesi Rp 4,26 triliun, Bali-NTT-NTB Rp 3,45 triliun, serta Mauluku \& Papua Rp1,27 triliun. Dimasa yang akan datang diharapkan akan semakin menyebar secara menyeluruh dengan jumlah investor yang lebih banyak lagi dari berbagai wilayah di Indonesia.

Berikut adalah perkembangan pasar modal syariah yaitu jumlah pengguna reksadana syariah, SBN, sukuk dan saham syariah ${ }^{18}$ data diperoleh dari OJK per 1 Maret 2019.

Tabel 4. Perkembangan Pasar Modal Indonesia tahun 2018

\begin{tabular}{|l|c|c|c|c|}
\hline Produk & $\begin{array}{c}\text { Reksadana } \\
\text { Pasar Modal Syariah }\end{array}$ & $\begin{array}{c}\text { SBN } \\
\text { Syariah }\end{array}$ & $\begin{array}{c}\text { Sukuk } \\
\text { Syariah }\end{array}$ & Saham Syariah \\
\hline Nilai Efek Syariah & $37,09 \mathrm{~T}$ & $731,48 \mathrm{~T}$ & $23,92 \%$ & $3,847 \mathrm{~T}$ \\
& $(7,08 \%)$ & $(19,37 \%)$ & $(5,52 \%)$ & $(52,05 \%$ \\
\hline Jumlah Efek Syariah & $233(11,12 \%)$ & $68(35,98 \%)$ & $120(16,33 \%)$ & $414(60 \%)$ \\
\hline
\end{tabular}

Dari data di atas bahwa jelas terlihat pasar modal syariah sudah berkembang dengan pesat dengan jumlah saham syariah yang telah menguasai lebih dari separuh pasar saham Indonesia dengan nilai efek syariah sebesar 3,847 T dengan jumlah efek syariah 414 atau setara dengan $60 \%$. Selain saham syariah produk pasar modal syariah yang lain yang tak kalah hebat adalah reksadana syariah dan sukuk serta SBN.

Daftar Efek Syariah (DES) adalah kumpulan Efek yang tidak bertentangan dengan Prinsip-prinsip Syariah di Pasar Modal, yang ditetapkan oleh Bapepam-LK atau Pihak yang disetujui Bapepam-LK. DES tersebut merupakan panduan investasi bagi Reksa Dana Syariah dalam menempatkan dana kelolaannya serta juga dapat dipergunakan oleh investor yang mempunyai keinginan untuk berinvestasi pada portofolio Efek Syariah. DES Periodik merupakan DES yang diterbitkan secara berkala yaitu pada akhir Mei dan November setiap

18 Komunitas Pasar Modal Indonesia, 'Perkembangan Pasar Modal Syariah' (Jakarta, 2018) <www.instagram/pasar_modal_syariah> [accessed 21 March 2019]. 
tahunnya. Berikut adalah jumlah saham syariah dalam Daftar Efek syariah dan Kapitalisasi Pasar Bursa Efek Indonesia ${ }^{19}$.

Tabel 5. Jumlah Saham Syariah dalam Daftar Efek Syariah (DES) per Februari 2019

\begin{tabular}{|c|c|c|}
\hline Tahun & Periode 1 & Periode 2 \\
\hline 2013 & 310 & 336 \\
\hline 2014 & 322 & 334 \\
\hline 2015 & 331 & 331 \\
\hline 2016 & 321 & 345 \\
\hline 2017 & 368 & 393 \\
\hline 2018 & 407 & 414 \\
\hline
\end{tabular}

Daftar Efaek Syariah (DES) Periode 2 tahun 2018 ditetakan melalui SK Dewan Komisioner OJK No.Kep.72/D.04/2018 tentang Daftar Efek Syariah yang berlaku 1 Desember 2018 sampai dengan 31 Mei 2019. Dari data diatas menunjukkan bahwa pada tahun 2013 periode 1; 310 dan periode 2; 336 berkembang sangat baik bahkan jika dilihat tahun berlakunya DES pada tahun 2018 periode 1; 407 kemudian pada periode 2; sebanyak 414. Hal ini menunjukkan bahwa daftar efek syariah sudah bisa bersaing dengan efek konvensional yang berjumlah 600 lebih bahkan setengah lebih dari jumlah efek di BEI sudah menjadi efek syariah.

Tabel 6. Kapitalisasi Pasar Bursa Efek Indonesia (Rp.Miliar)

\begin{tabular}{|c|c|c|c|}
\hline Tahun & $\begin{array}{c}\text { JII } \\
\text { (Jakarta Islamic Index) }\end{array}$ & $\begin{array}{c}\text { ISSI } \\
\text { (index Saham Syariah } \\
\text { Indonesia) }\end{array}$ & $\begin{array}{c}\text { JII 70 } \\
\text { (Jakarta Islamic Index } \\
\text { 70) }\end{array}$ \\
\hline 2011 & $1.414 .983,81$ & $1.968 .091,37$ & \\
\hline 2012 & $1.671 .004,23$ & $2.451 .334,37$ & \\
\hline 2013 & $1.672 .004,23$ & $2.557 .846,77$ & \\
\hline 2014 & $1.944 .531,70$ & $2.946 .892,79$ & \\
\hline 2015 & $1.737 .290,98$ & $2.600 .850,72$ & \\
\hline 2016 & $2.035 .189,92$ & $3.170 .056,08$ & $2.715 .851,74$ \\
\hline 2017 & $2.288 .015,67$ & $3.704 .543,09$ & $2.895 .377,71$ \\
\hline 2018 & $2.239 .509,78$ & $3.666 .688,31$ & $2.800 .124,5$ \\
\hline 2019 & Januari $2.376 .039,14$ & $3.861 .714,08$ & \\
\hline \multicolumn{5}{r}{ Februari $2.281 .962,48$} & $3.819 .522,48$ & \\
\hline
\end{tabular}

19 OJK, 'Saham Syariah', OJK.Co.Id, 2019 <https://www.ojk.go.id/id/kanal/syariah/data-dan-statistik/sahamsyariah/Documents/Pages/Statistik-Saham-Syariah> [accessed 21 March 2019]. 
Indeks saham syariah itu ada Jakarta Islamic Indeks (JII) terbagi dalam JII 30 dan JII 70 artinya semua saham syariah yang ada di Jll 30 berarti saham-saham syariah yang sering ditransaksikan ada 30 saham syariah begitupun yang terdapat dalam JII 70, ada 70 saham syariah yang diminati dan ditransaksikan oleh para investor. Sedangkan indeks lainnya adalah Indeks Saham Syariah Indonesia (ISSI) merupakan seluruh saham-saham syariah yang ada di transaksikan dalam Bursa Efek Indonesia. jika dilihat dari data diatas, terlihat jelas ada peningkatan transaksi setiap tahunnya, walaupun ada yang turun namun secara rata-rata terjadi kenaikan setiap tahunnya misalnya pada tahun 2018 pada indeks JII 2.239.509,78, indeks ISSI sebesar 3.666.688,31 lalu pada JII70 ada sebesar 2.715.851,74 sementara itu tahun 2019 pada bulan Januari; indeks JII 2.376.039,14, indeks ISSI sebesar 3.861.714,08 dan indeks JII70 sebesar 2.895.377,71 kemudian pada bulan Februari pada indeks JII 2.281.962,48 sementara pada indeks ISSI sebesar 3.819.522,48, ada penurunan pada bulan februari pada indeks JII70 dengan jumlah transaksi sebesar 2.800.124,5.

\section{KESIMPULAN}

Pasar modal syariah sudah berkembang dengan baik, produk yang ada di pasar modal syariah itu berupa reksadana syariah, sukuk, SBN Syariah dan saham syariah. Khusus dalam penulisan jurnal ini adalah saham syariah. Untuk menjadi investor saham syariah sangat mudah dengan menyediakan photo copy KTP, buku tabungan, NPWP, pergi ke sekuritas, uang Rp.100.000 kemudian sudah bisa bertransaksi atau melalui Sharia Online Trading System (SOTS). Legalitas investasi saham sayriah pun sudah diatur dalam Al-qur'an dan Hadits, Fatwa DSN-MUI, ljma dll.

Dalam perkembangannya investasi saham syariah sudah menunjukkan perkembangan yang sangat pesat bisa dilihat dari jumlah investor, penyebaran investor di seluruh Indonesia, jumlah transaksi dari tahun ketahun menunjukkan peningkatan, sosialisasinya melalui sekolah pasar modal yang diadakan di seluruh Indonesia kepada masyarakat luas.

\section{DAFTAR PUSTAKA}

Abdalloh, Irwan, Pasar Modal Syariah (Jakarta: PT Elex Komputindo, 2018)

Akucintakeuangansyariah.com, 'Mengenal Investasi Yang Amanah: Pasar Modal Syariah', 2019

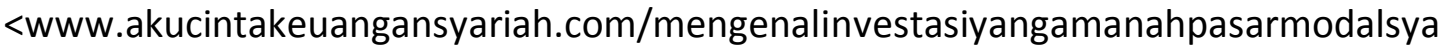
riah> [accessed 21 March 2019]

Al-Nisa, Qoonitah Fithri, 'PERBANDINGAN ANTARA RETURN SAHAM SYARIAH DAN SAHAM KONVENSIONAL DI BURSA EFEK INDONESIA (PENDEKATAN VEKTOR ERROR CORRECTION MODEL)', INKLUSIF (JURNAL PENGKAJIAN PENELITIAN EKONOMI DAN HUKUM ISLAM), 3 (2018), 147-55

Aldin, Ihya Ulum, 'Investor Melenial Semakin Mendominasi Pasar Modal', Katadata.Co.Id, $2018<$ <ttps://katadata.co.id/berita/2018/12/27/investor-milenial-semakinmendominasi-pasar-modal> [accessed 18 March 2019] 
Bank Indoensia, UU RI No.19 Tahun 2008 Tentang Surat Berharga Syariah Negara (Indonesia, 2008) <https://www.bi.go.id/id/tentang-bi/uubi/Documents/UU19Tahun2008SBSN.pdf>

BEI, 'IDX Syariah', BEI, 2018 <http://www.idx.co.id/idx-syariah/> [accessed 19 February 2019]

Bungin, Burhan, Penelitian Kualitatif: Komunikasi, Ekonomi, Kebijakan Publik, Dan IImu Sosial Lainnya, Jakarta: Kencana, 2011 <https://doi.org/10.1002/jcc.21776>

Darmawan, Haris, 'Bagaimana Cara Membuka Rekening Saham Dan Mulai Membeli Saham', 18 April, $2017<w w w$. Financialku.com> [accessed 14 March 2019]

$\begin{array}{llll}\text { DSN-MUI, 'DSNMUI No.80/DSNMUI/III/2011', } & \text { DSN-MUI, } & 2019\end{array}$ <https://dsnmui.or.id/category/fatwa/page/5/> [accessed 10 March 2019]

$\begin{array}{llll}-- & \text { 'Fatwa Akad Pasar Modal Syariah', DSN-MUI, } 2019\end{array}$ <https://dsnmui.or.id/category/fatwa> [accessed 1 March 2019]

Hadyan, Rezha, 'Ini Strategi BEl Menggenjot Investor Saham Syariah Indonesia', Kontan.Co.ld, $2019 \quad<$ https://investasi.kontan.co.id/news/ini-strategi-beimenggenjot-investor-saham-syariah-di-indonesia> [accessed 13 February 2019]

Hendartyo, Muhammad, 'BEI Bidik 100 Ribu Investasi Saham Syariah 2019', Bisnis.Tempo.Co (Jakarta, 9 February 2019)

IDX Islamic, 'Produk Syariah', IDX Is/amic, 2018 <http://www.idx.co.id/idx-syariah/produksyariah> [accessed 15 November 2018]

- - , 'Syariah Online Trading System', IDX Islamic, $2018<$ https://www.idx.co.id/idxsyariah/transaksi-sesuai-syariah> [accessed 14 March 2019]

Komunitas Pasar Modal Indonesia, 'Perkembangan Pasar Modal Syariah' (Jakarta, 2018) $<$ www.instagram/pasar_modal_syariah> [accessed 21 March 2019]

Latief, Zulbiladi, 'Hukum Jual Beli Saham Dan Bursa Efek Dalam Islam Dan MUI', Analisis.Co.Id, 2017 <https://analis.co.id/hukum-saham-mui.htm> [accessed 2 June 2018]

Mardani, Fiqih Ekonomi Syariah (Jakarta: Prenada Media, 2012)

Nurlita, Anna, 'Investasi Di Pasar Modal Syariah Dalam Kajian Islam', Kutubkhanah, 17 (2015), 1-20

OJK, 'Pasar Modal Syariah', OJK, 2017 <https://www.ojk.go.id/id/kanal/syariah/tentangsyariah/pages/pasar-modal-syariah.aspx> [accessed 14 March 2019]

- - , 'Saham Syariah', OJK.Co.Id, 2019 <https://www.ojk.go.id/id/kanal/syariah/data-danstatistik/saham-syariah/Documents/Pages/Statistik-Saham-Syariah> [accessed 21 March 2019]

P3El. Pusat Pengkajian dan Pengembangan Ekonomi Islam, Ekonomi Islam (Jakarta: Rajawali, 2013)

Selasi, Dini, Moderasi Islam Di Era Distrupsi Dalam Pandangan Kearifan Lokal, Pendidikan Islam, Ekonomi Syariah, Fenomena Sosial Keagamaan (Yogyakarta: Gading Pustaka, 2018)

Sholihin, Ahmad Ifham, Buku Pintar Ekonomi (Jakarta: PT. Gramedia Pustaka Utama, 2010)

- - , Buku Pinter Ekonomi (Jakarta: PT. Gramedia Pustaka Utama, 2010)

Simamora, Novita Sari, 'Indeks Saham Syariah Indonesia Tumbuh Tertinggi Di Dunia', Financialbisnis.Com, 2016

Yustria, Derry, Workshop Pasar Modal Syariah-Pasar Modal Syariah Indonesia (Indramayu, 
2019)

Zed, Mustika, Metode Penelitian Kepustakaan (Jakarta: Yayasan Obor Indonesia, 2008) 